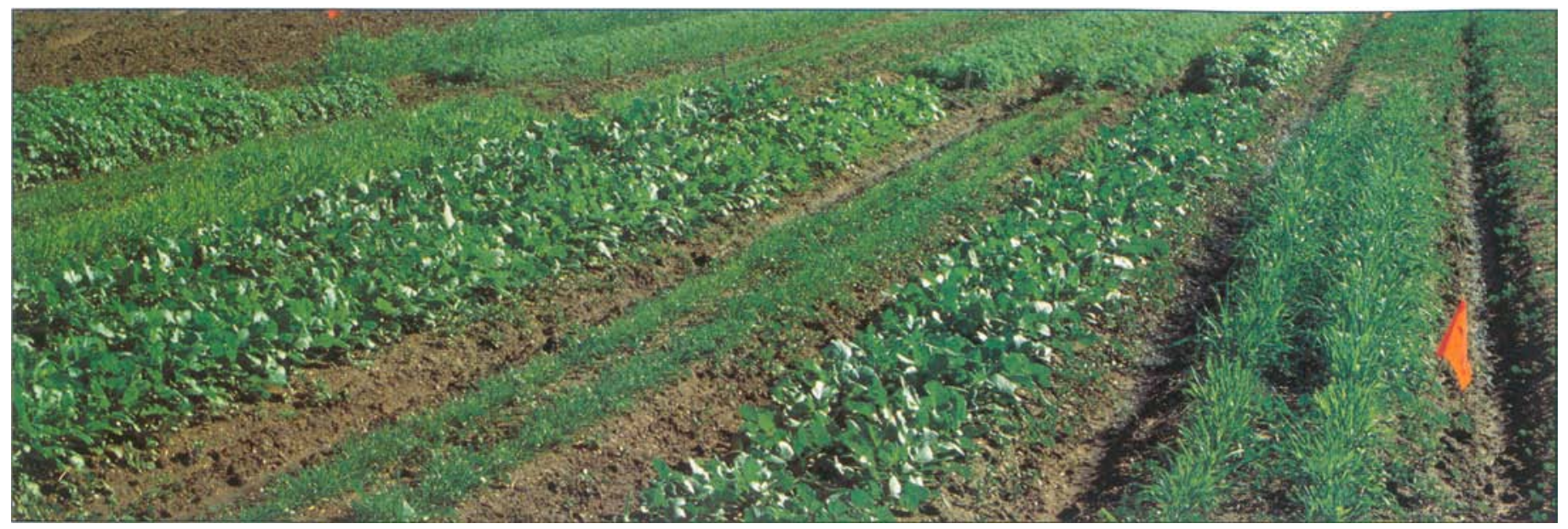

In lettuce production ...

\title{
Winter cover crops can decrease soil nitrate, leaching potential
}

\begin{abstract}
Louise E. Jackson
Steven T. Koike

The large amounts of soil nitrate that can accumulate in annual row crop production during the winter fallow period can leach during winter storms and spring irrigation. In Monterey County, $48 \%$ of the wells in the upper unconfined aquifer exceed the public health drinking water standard of $10 \mathrm{ppm}$ of nitrate-N. Nonleguminous cover crops, planted during the winter fallow and incorporated in early spring using reduced tillage equipment to maintain intact beds, have been found to reduce nitrate leaching without disrupting cropping schedules.
\end{abstract}

The most efficient use of fertilizer and soil-derived nitrogen $(N)$ occurs when availability coincides with plant demand. In cool-season vegetable production systems, most nitrate leaching occurs: (1) in the fallow period during winter rains when excess soil nitrate accumulates from residual fertilizer and from $\mathrm{N}$ mineralization and nitrification of crop residues and soil organic matter, and (2) during frequent irrigations in the final vegetable production growth stages.

Test results in the Salinas Valley show that high soil nitrate levels remain after vegetable harvest, and that concentrations often double during the winter fallow; net $\mathrm{N}$ mineralization reaches its annual maximum at this time. One objective in trying to reduce nitrate leaching therefore involves ways to recycle the excess residual soil $\mathrm{N}$ after the autumn harvest and to synchronize its release with uptake by the subsequent vegetable crop in early spring.

In other cropping systems, nonleguminous winter cover crops have been successfully employed to take up excess water and nitrate during the rainy fallow season, as well as to contribute to soil organic matter content after incorporation. A large volume of research has shown that increased organic matter leads to increased microbial activity in the soil, greater soil $\mathrm{N}$ turnover, greater aggregate stability, decreased soil crusting, increased water infiltration and ultimately enhanced fertility for the subsequent cash crop. With the development of techniques to grow and incorporate cover crops directly on semi-permanent beds, the constraints of time and expense typically involved in disking and reshaping beds will be eliminated.

In other studies, cover cropping has been shown to affect crop disease and insect pest management both positively and negatively. Cover crop cultivation may promote some soil fungal pathogens. Previous research has found that some cover crops can increase Sclerotinia minor inoculum which, combined with reduced tillage techniques, might threaten subsequent lettuce crops. Cover crop residue and reduced tillage prac- tices can also increase some soil insect populations, although this can be beneficial in the case of natural predators. Cover crops and crop rotations have also been shown to suppress some soilborne diseases. For example, a study conducted in Salinas in 1986-88 found that corky root of lettuce can be partially suppressed by a winter cover crop of cereal rye.

\section{Field station trials}

A preliminary trial, conducted on field station plots, evaluated several species for use as winter cover crops in rotation with annual row crops in the Salinas Valley. Desired characteristics included rapid growth and extensive root development in the upper soil profile during winter, to maximize nitrate and water uptake. In addition, it was assumed that the cover crop should be easy to incorporate on the beds, using minimum tillage techniques, and should not harbor diseases threatening to the subsequent cash crop.

Methods. A cover crop trial was established on field station research plots in Salinas, California, on November 15, 1989. Six species were planted in a randomized complete block design: oilseed radish (Raphanus sativus cv. Renova), white senf mustard (Brassica hirta cv. Martigena), white mustard (Brassica alba), phacelia (Phacelia tanacetifolia cv. Phaci), rye (Secale cereale cv. Merced) and annual ryegrass (Lolitum multiflorum), along with a bare fallow plot in each block as a control. Soil samples to $60 \mathrm{~cm}$ 
Left, field station cover crop trial at Salinas in December, 1989, one month after planting. Cover crops were seeded in two rows on 40-inch beds. Species (left to right) in the front row are: white senf mustard, annual rye grass, barley, oilseed radish, white mustard, annual ryegrass and Merced rye. Phacelia is in the second row in lines 4 and 5 from the right side of the plot.

Right, on-farm cover crop trial at Salinas in February, 2.5 months after planting. Treatments (left to right) are: bare soil, phacelia and Merced rye.

(24 inches) deep were taken at planting in midseason (January 7, 1990) and before incorporation (March 8, 1990). The stands were incorporated on March 20 to a depth of $20 \mathrm{~cm}$ (8 inches) with a rotary tiller (Marvin Rowmaster bedshaper/incorporator). Soil samples were taken weekly from the top $15 \mathrm{~cm}$ (6 inches) soil layer for 7 weeks following incorporation.

Phacelia and Merced rye were selected from the 1989-90 experiments as the most promising of the cover crops for the second year of the study because of their fibrous root systems and diffuse growth forms, which facilitate direct incorporation on pre-formed beds. The cruciferous cover crops were not chosen because they are potential alternate hosts for Brassica cash crop diseases such as turnip mosaic virus. Phacelia has been used in sugar beet rotations as a cyst nematode trap crop. It is mildly susceptible to beet western yellows virus, and mature flowering stands have been found to harbor Lygus spp.

In the second year of this study, phacelia and Merced rye were seeded on November 13, 1990, after a preplant soil sample was taken. The design was a randomized complete block, with a bare fallow control plot in each of six blocks. Subsequent soil samples were taken on January 2 and February 12, 1991. Plant shoot and root samples were also collected on these dates. The cover crops were incorporated on the beds with a rotary tiller on February 12.

All soil samples were extracted in 2 moles/liter potassium chloride $(\mathrm{KCl})$, and the supernatant was analyzed for nitrate and ammonium content with a Wescan Ammonia Analyzer. Gravimetric soil moisture content was determined for each sample. Net mineralizable $\mathrm{N}$ was determined using a 7-day anaerobic incubation procedure. Aboveground plant and root samples were oven-dried at $65^{\circ} \mathrm{C}\left(150^{\circ} \mathrm{F}\right)$, weighed and analyzed for total $N$ by the Kjeldahl method.

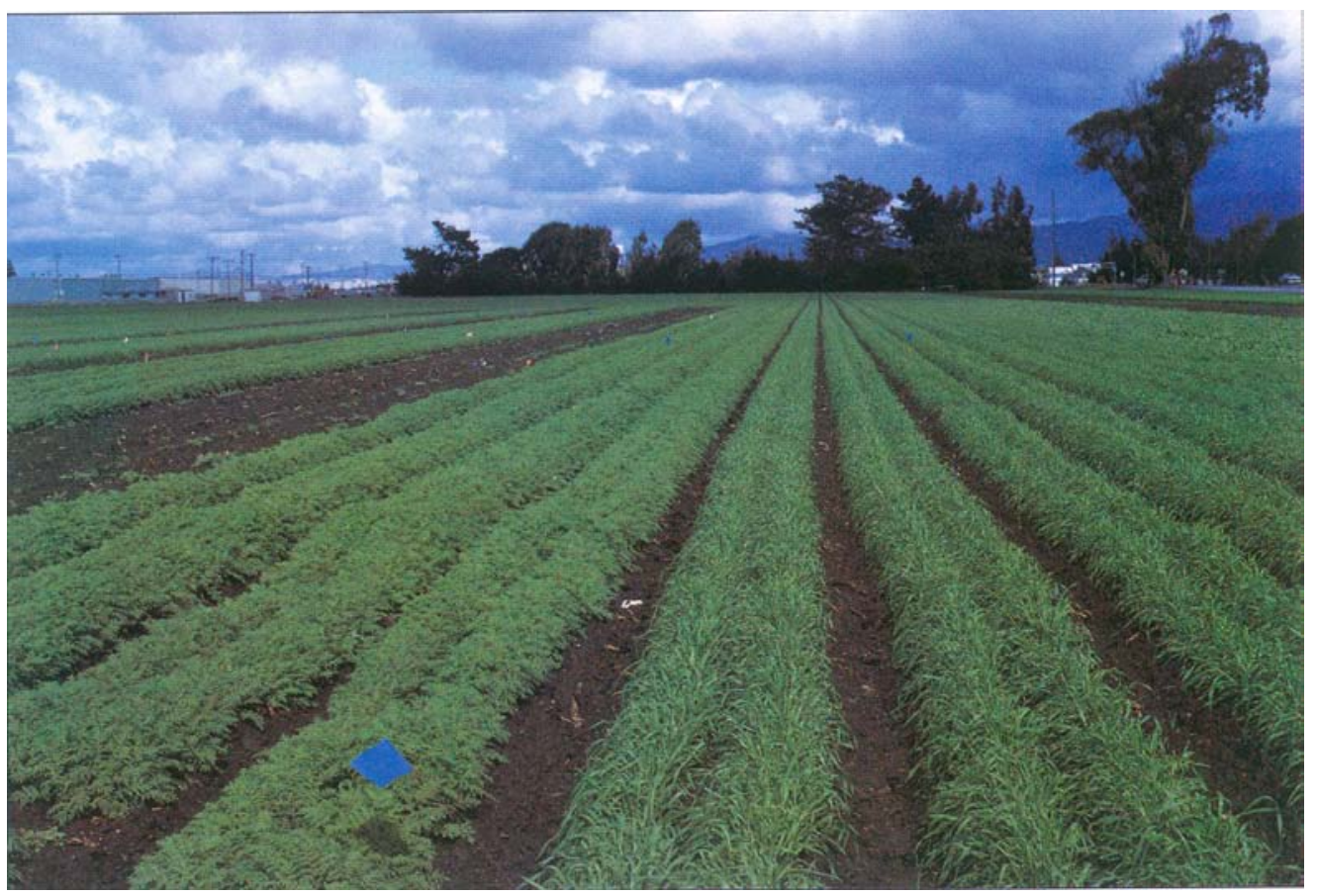

Results. Cover crops significantly reduced soil moisture and nitrate concentrations relative to a fallow control during the winter of 1989-90 (fig. 1). By the time of incorporation in March 1990 , the average nitrate concentration in the cover-cropped plots $(0$ to $30 \mathrm{~cm}$, or 0 to 12 inches, deep) was $15 \mu \mathrm{g}$ nitrate- $\mathrm{N}$ per gram $\left(\mathrm{NO}_{3}{ }^{-}-\mathrm{N} / \mathrm{g}\right)$ soil lower than the bare soil plots, which is equal to a difference of $63 \mathrm{~kg} \mathrm{NO}{ }^{-}-\mathrm{N} /$ ha $\left(71 \mathrm{lb} \mathrm{NO}_{3}{ }^{-}-\right.$

$\mathrm{N} /$ acre). In addition, the cover-cropped plots sustained a higher level of microbial activity, as indicated by higher net mineralizable $\mathrm{N}$ concentrations: $36.2 \pm$ $5.19 \mu \mathrm{g}$ ammonium-N per gram $\left(\mathrm{NH}_{4}{ }^{+-}\right.$ $\mathrm{N} / \mathrm{g}$ ) soil in cover-cropped soil versus $10.4 \pm 0.67 \mu \mathrm{g} \mathrm{NH}_{4}{ }^{+-\mathrm{N}} / \mathrm{g}$ soil in the bare soil ( $x \pm$ S.E.), averaged over 7 sampling dates in the 7 weeks following incorporation.

In the study's second year, the winter of 1990-91, rainfall was $15.1 \mathrm{~cm}(5.94$ inches) below average. Soil nitrate concentrations increased 500 to $540 \mathrm{~kg} \mathrm{NO} 3$ $-\mathrm{N} /$ ha (446 to $482 \mathrm{lb} / \mathrm{acre}$ ) in the covercropped plots and $650 \mathrm{~kg} \mathrm{NO}_{3}^{--} \mathrm{N} / \mathrm{ha}$ ( $580 \mathrm{lb} /$ acre) in the bare plots ( 0 to 60 $\mathrm{cm}$, or 0 to 24 inches, deep). This large increase illustrates the magnitude of net mineralization and nitrification that leads to soil nitrate accumulation.

Aboveground biomass production in the second year by phacelia and Merced rye was similar, averaging $1,600 \mathrm{~kg} / \mathrm{ha}$ $(1,427 \mathrm{lb} /$ acre) after a 13 -week growing period that included both severe cold and drought. Root biomass averaged 490 $\mathrm{kg} / \mathrm{ha}(437 \mathrm{lb} / \mathrm{acre})$ at a depth of 0 to 60 $\mathrm{cm}$ (0 to 24 inches) for both species. The majority of roots were located in the top $30 \mathrm{~cm}$ (12 inches) of soil, which coin- cided with the zone of greatest nitrate depletion.

\section{On-farm trials}

Although cover ps can reduce nitrate leaching and : ease soil $N$ turnover, it is difficult in commercial practice to include them in crop rotations because of the time required for disking, listing and shaping beds before planting the cash crop. In 1991, we initiated a series of on-farm studies that included developing reduced tillage techniques to incorporate cover crops directly on the beds into which the subsequent crop
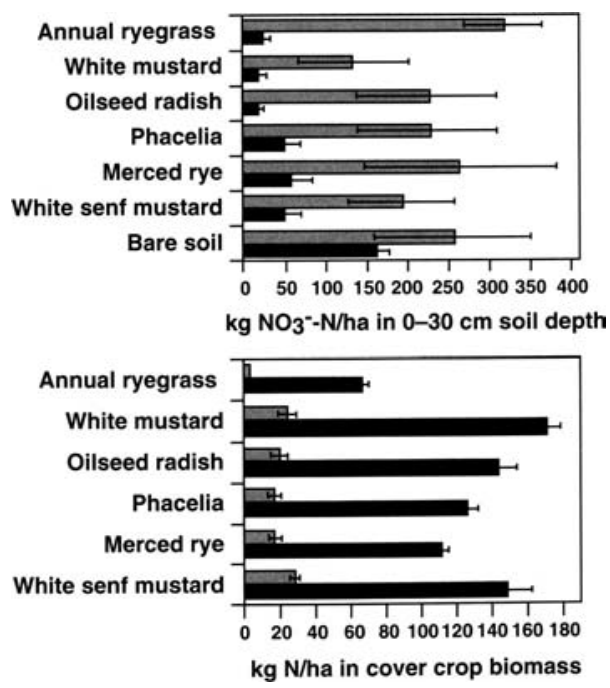

Fig. 1 Mean nitrate content in the top $30 \mathrm{~cm}$ of soil, and $\mathbf{N}$ in the aboveground biomass of six cover crops compared to a bare soil control at mid-season in January (gray) and at incorporation in March (black), in an experimental trial in Salinas in 1990. 


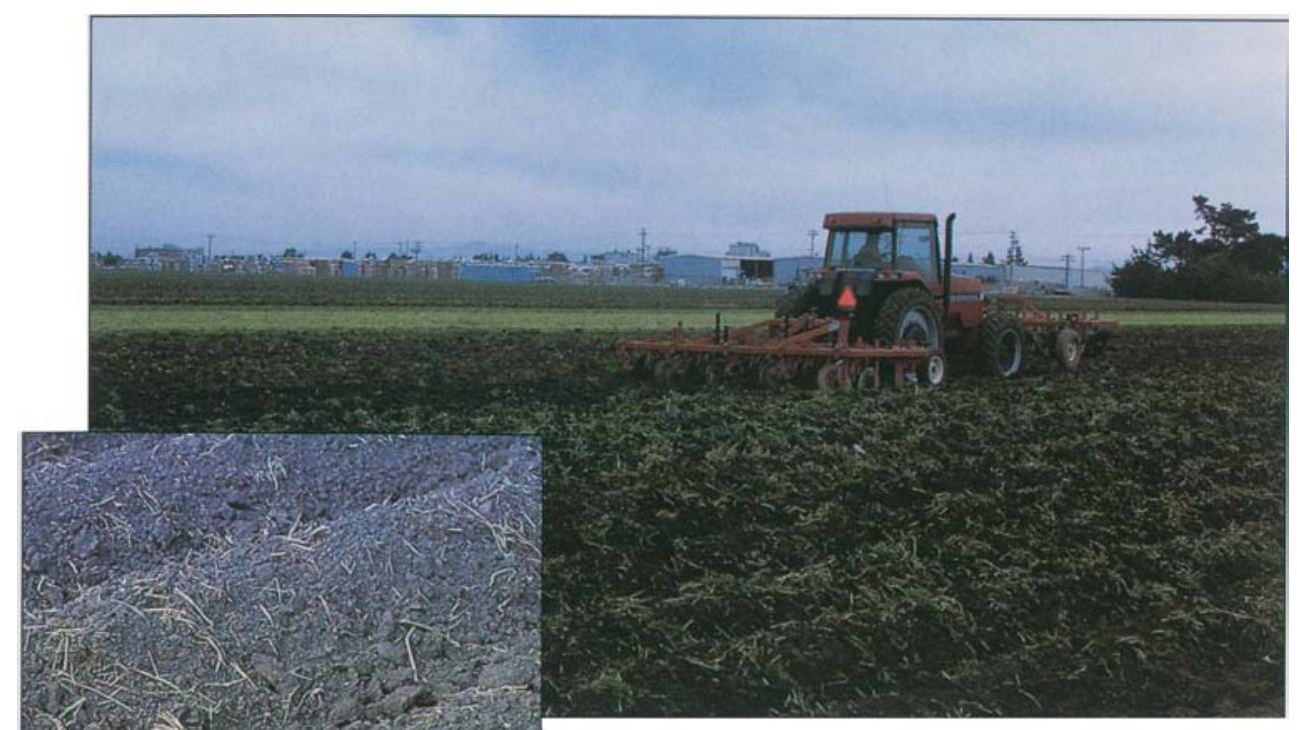

Incorporation of cover crops on established beds with a Sundance System. Inset, decomposing residues of Merced rye cover crop in established beds approximately 3 weeks after incorporation. Note resprouting from some of the plant crowns.

was to be direct-seeded. Growth and disease incidence were monitored in the lettuce crops at these sites to determine whether they were affected by the presence of cover crop residues.

Methods. In the autumn of 1991, cover crop trials were established at three farm sites in Salinas, California, that were subsequently planted with crisphead lettuce following cover crop incorporation. The three farms encompassed several management regimes for large-scale production of vegetables.

Farm 1 utilized a fall-planted phacelia cover crop. The site was a 9.7-ha (24acre) field on a Chualar loam soil type. Phacelia was planted on September 7 at $3.5 \mathrm{~kg} / \mathrm{ha}$ ( $3.1 \mathrm{lb} / \mathrm{acre}$ ) and sprinklerirrigated to a stand. Two areas of the field were left unplanted (bare) as a control. The crop was incorporated on November 6 using a rotary chopper followed by two passes with a Sundance System to maintain intact beds. Soil samples were taken from the covercropped and corresponding bare plots 2 days before cover crop planting and 2 days after incorporation. Lettuce was planted on December 28. Lettuce samples were collected just before harvest to measure biomass and $\mathrm{N}$ content.

Farm 2 was a 3.5 -ha (8.6-acre) subsurface drip-irrigated site on a Salinas clay loam. Merced rye ( $40 \mathrm{~kg} / \mathrm{ha}$, or $35.7 \mathrm{lb}$ ) acre), phacelia (10 kg/ha, $8.9 \mathrm{lb} /$ acre) and oilseed radish $(17.5 \mathrm{~kg} / \mathrm{ha}, 15.6 \mathrm{lb} /$ acre) were planted on September 5, each with corresponding bare control plots. The field was drip-irrigated until October 11. Soil samples were taken at cover crop planting and a week before incorporation, when cover crop biomass samples were collected. Incorporation took place on October 23, using a flail shredder and then a Sundance System to incorporate the cover crops without disturbing the drip tubing. Lettuce was direct-seeded approximately 2 months later. Lettuce samples were collected at thinning, March 2, 1992, and at harvest, April 27.

Farm 3 delayed planting cover crops until December, after harvesting cole crops in late August. The site was 5.7 ha (14 acres) on a Salinas clay loam soil. Two soil samples were taken before cover crop planting: one on September 17 and one on November 14, 1991. Phacelia and Merced rye were planted on December 6 in a randomized complete block design that included a bare fallow control. The field was sprinklerirrigated 1 and 2 weeks after planting. Aboveground plant samples were collected from the cover crops throughout the season to measure dry matter and total N accumulation. On February 28 , 1992, the cover crops were flail mowed and then incorporated with a Sundance System. Soil samples were taken before planting, at midseason, at cover crop in- corporation, at lettuce planting (April 22, 1992), at thinning (May 20) and at harvest (June 29). Lettuce plant samples were collected at thinning and at harvest.

Soil samples from all sites were processed by extraction in 2 moles / liter $\mathrm{KCl}$, and analyzed for nitrate and ammonium content as described above. A separate sample from each depth was taken for gravimetric measurement of soil moisture. Samples at Farms 1 and 2 were taken to $45 \mathrm{~cm}$ (18 inches) deep and divided into two depth increments ( 0 to 15 and 15 to $45 \mathrm{~cm}$ or 0 to 6 and 6 to 18 inches). Samples at Farm 3 were taken to $105 \mathrm{~cm}(3.5 \mathrm{ft})$ deep and divided into four depth increments. In addition, samples from the top ( 0 to 15 and 15 to $30 \mathrm{~cm}$, or 0 to 6 and 6 to 12 inches) soil layers at Farm 3 were analyzed for net mineralizable $N$ using an anaerobic incubation assay. Cover crop and lettuce plant samples were oven-dried, weighed to determine dry matter accumulation, ground and analyzed for total $\mathrm{N}$ content by Kjeldahl digestion. Data analysis was conducted using t-tests or analysis of variance. Statistical significance was set at $P<0.05$ for all tests unless otherwise indicated.

Results. At Farm 1, phacelia plots contained significantly lower nitrate and moisture levels than bare soil plots after 8 weeks of growth. The nitrate content of bare soil exceeded cover-cropped soil by $11.0 \mathrm{~kg} \mathrm{NO} 3^{-}-\mathrm{N} / \mathrm{ha}(9.8 \mathrm{lb} /$ acre $)$ in the 0 - to $15-\mathrm{cm}$ soil layer, and by $61.7 \mathrm{~kg}$ $\mathrm{NO}_{3}-\mathrm{-N} /$ ha $(55.0 \mathrm{lb} / \mathrm{acre})$ in the $15-$ to $45-\mathrm{cm}$ soil layer. There were no significant differences in the dry weight or $\mathrm{N}$ content of the lettuce collected at harvest from the cover-cropped and bare plots. The lettuce crop was evaluated for corky root and Sclerotinia diseases, and there was no difference in disease incidence between treatments.

Farm 2, utilizing subsurface irrigation, displayed similar trends for several cover crops. Phacelia significantly reduced soil nitrate at both sampling depths compared with adjacent bare

\begin{tabular}{|c|c|c|c|c|c|}
\hline \multirow{3}{*}{$\begin{array}{l}\text { Soil } \\
\text { depth }\end{array}$} & \multicolumn{5}{|c|}{ Soil nitrate $\left(\mathrm{kg} \mathrm{NO}_{3}{ }^{-}-\mathrm{N} / \mathrm{ha}\right)$} \\
\hline & \multicolumn{2}{|c|}{$\begin{array}{l}\text { Before } 1991 \text { cover } \\
\text { crop planting* }\end{array}$} & \multicolumn{3}{|c|}{$\begin{array}{l}\text { After } 1992 \text { cover crop } \\
\text { incorporation (March)* }\end{array}$} \\
\hline & September & November & Phacelia & M. rye & Bare soil \\
\hline \multicolumn{6}{|l|}{$\mathrm{cm}$} \\
\hline $0-15$ & $21.7 \pm 2.70$ & $48.3 \pm 9.11$ & $15.6 \pm 2.24$ & $12.1 \pm 3.13$ & $10.9 \pm 0.95$ \\
\hline $15-45$ & $9.8 \pm 0.55$ & $29.2 \pm 3.02$ & $17.8 \pm 2.08$ & $14.8 \pm 1.21$ & $24.9 \pm 2.33$ \\
\hline $45-75$ & $14.3 \pm 2.91$ & $23.8 \pm 5.52$ & $12.5 \pm 0.92$ & $11.9 \pm 1.23$ & $44.2 \pm 3.62$ \\
\hline $75-105$ & $10.6 \pm 2.41$ & $27.1 \pm 5.02$ & $8.5 \pm 1.09$ & $14.1 \pm 1.29$ & $42.6 \pm 6.55$ \\
\hline
\end{tabular}


plots, rye reduced soil nitrate levels at 15 to $45 \mathrm{~cm}$ deep, and radish reduced nitrate levels at 0 to $15 \mathrm{~cm}$ deep. In the entire 0 - to $45-\mathrm{cm}$ profile, the bare plots contained $34.1,59.4$ and $201.7 \mathrm{~kg} \mathrm{NO}_{3}^{--}$ $\mathrm{N} / \mathrm{ha}(30.4,53.0$ and $180.0 \mathrm{lb} /$ acre $)$ more than their corresponding phacelia, rye and radish plots, respectively. Soil moisture was reduced by the presence of cover crops in all plots. Oilseed radish produced approximately twice the biomass, with twice the $\mathrm{N}$ content, as the phacelia and rye in this short (7-week) growing period. Total aboveground biomass production was $1,250,1,355$ and $2,761 \mathrm{~kg} / \mathrm{ha}(1,115,1,208$ and $2,463 \mathrm{lb} /$ acre) from phacelia, rye and radish crops, respectively. The corresponding $\mathrm{N}$ content of these cover crops was 54.9, 57.0 and $113.5 \mathrm{~kg} \mathrm{~N} / \mathrm{ha}(49.0,50.8$ and $101.2 \mathrm{lb} /$ acre). There were no significant differences in the dry weight or $\mathrm{N}$ content of the lettuce harvested from all cover-cropped and adjacent bare plots. Sclerotinia infection was minimal in this field, and there was no difference observed between treatments.

At Farm 3, the soil nitrate level following the autumn vegetable harvest was $56.4 \mathrm{~kg} \mathrm{NO} 3^{--}-\mathrm{N} /$ ha $(50.3 \mathrm{lb} /$ acre $)$ at a depth of 0 to $105 \mathrm{~cm}(0$ to $3.5 \mathrm{ft})$, and it more than doubled to $128.4 \mathrm{~kg} \mathrm{NO} 3^{--} \mathrm{N} /$ ha (114.5 lb/acre) in the next 2 months of fallow before the cover crops were planted (table 1). Cover crops significantly depleted soil nitrate to a depth of

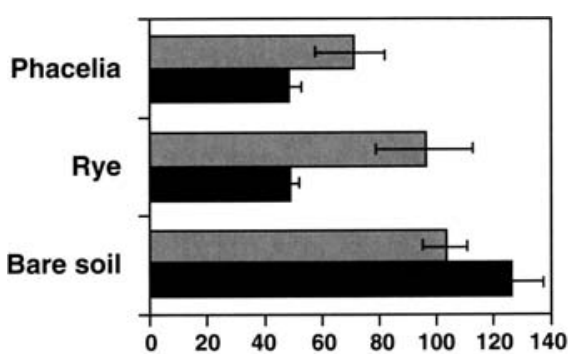

kg NO${ }^{--}-\mathrm{N} / \mathrm{ha}$ in $0-105 \mathrm{~cm}$ soil depth

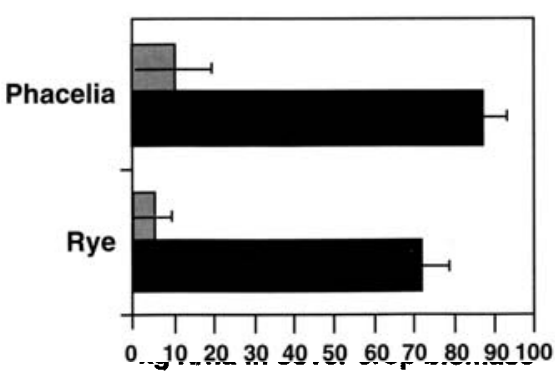

Fig. 2. Mean nitrate content to $105 \mathrm{~cm}$ soil depth, and $\mathbf{N}$ in aboveground biomass of two cover crops compared to a bare soil control at mid-season in January (gray) and at incorporation in March (black), in a grower's field in Salinas in 1992.

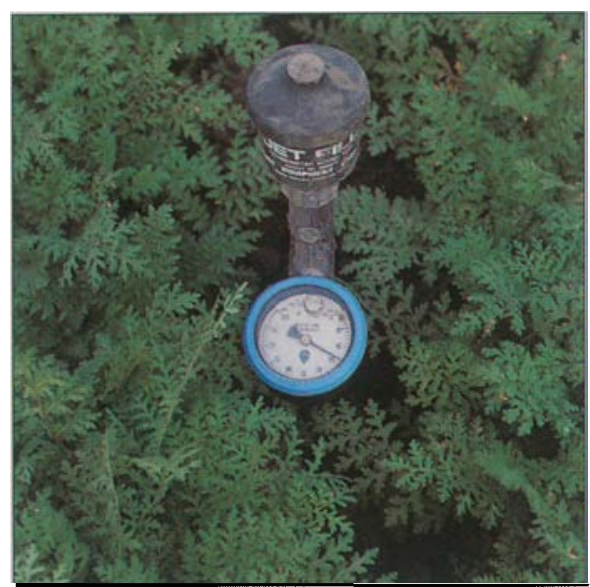

Phacelia tanacetifolia after 2 months of winter growth.

$105 \mathrm{~cm}$ relative to the bare plots by the time of incorporation, 12 weeks after planting (fig. 2). Soil nitrate at the lower depths in the bare plots increased during this time. Nitrate content was significantly lower in the cover-cropped plots compared with the bare fallow: $8.6 \mathrm{~kg}$ $\mathrm{NO}_{3}-\mathrm{N} /$ ha $(7.7 \mathrm{lb} /$ acre) lower in the $15-$ to $45-\mathrm{cm}$ soil depth, and 32.0 and $31.2 \mathrm{~kg}$ $\mathrm{NO}_{3}-\mathrm{N} / \mathrm{ha}(28.5$ and $27.8 \mathrm{lb} /$ acre) lower at the $45-$ to $75-\mathrm{cm}$ and 75- to $105-$ $\mathrm{cm}$ (18- to 30 -inch and 30- to 42-inch) soil depths, respectively (table 1). Soil moisture was significantly lower in the cover-cropped plots in the top two soil depths. Aboveground biomass production and $\mathrm{N}$ content of the phacelia was significantly greater than the rye $(23.3$ versus $8.0 \mathrm{~kg} \mathrm{~N} / \mathrm{ha}$, or 20.7 versus 7.1 $\mathrm{lb} /$ acre) after the first 6 weeks of growth. At incorporation, phacelia had produced significantly more biomass than the rye $(1,090$ and $810 \mathrm{Kg} / \mathrm{ha}$, or 972 and $722 \mathrm{lb} /$ acre, from phacelia and rye, respectively), but there was no difference in total $\mathrm{N} /$ ha between the two cover crops $(87.0$ and $71.6 \mathrm{~kg} \mathrm{~N} / \mathrm{ha}$, or 77.6 and $64.0 \mathrm{lb} /$ acre, from phacelia and rye, respectively). There were no significant differences in dry weight or $\mathrm{N}$ content of lettuce at thinning or at harvest between the cover-cropped and fallow plots. Sclerotinia infection was very low in this field, and no differences were observed between cover crop treatments in the incidence of either Sclerotinia or corky root of lettuce. No damping off (due to Pythium spp. or Rhizoctonia spp. root infections that damage and kill young seedlings) was observed in our experimental or on-farm field trials.

\section{Conclusions}

Data from all three on-farm trials confirm the conclusions of the earlier field station experimental trials. Nonleguminous cover crops grown during the rainy winter fallow season can success- fully decrease soil nitrate and reduce the potential for leaching. Of all the cover crops tested, phacelia was selected as the most advantageous for this cropping system because (1) it has fibrous roots and succulent tops that facilitate incorporation, (2) it is late-flowering and can withstand cool coastal winters, (3) it does not harbor the diseases of the cruciferous cover crops and (4) it does not resprout after incorporation using reduced tillage techniques, which is typical of the grasses. Although phacelia is native to California, it is presently being bred for use as a cover crop only in Europe, and seed availability in this country is limited. As phacelia becomes more widely recognized as a valuable winter cover crop in this region, its availability and affordability are expected to improve. We found it possible to grow and incorporate cover crops on semipermanent beds using reduced tillage equipment such as the Sundance System or a power-driven bed shaper/incorporator after flail-mowing the stand.

By reducing the time and energy required for management, integrating a winter cover crop rotation into conventional farming practices becomes more feasible. No detrimental effect on lettuce crop yield was found at any of the sites as a result of having cover crops in the rotation. The fertilizer applied as a preplant and/or side-dress during lettuce crop production at all three field sites (between 100 and $150 \mathrm{~kg} \mathrm{~N} / \mathrm{ha}$, or 89.2 and $133.8 \mathrm{lb} /$ acre) probably masked the $\mathrm{N}$ contribution of the cover crops, and explains why there was no significant increase in the yield or $N$ content of the lettuce in the cover-cropped plots.

Future studies should test yields from cover-cropped and fallow soils with lower amounts of added fertilizer and in fields cover cropped for successive years, to determine the cumulative influence of cover cropping on soil fertility. Further research is also needed to provide a more in-depth evaluation of the effect of cover cropping on plant disease and insect pest incidence as well as other long-term management effects and economic profitability.

L. E. Jackson is Assistant Professor, Cooperative Extension Specialist and Physiologist, Department of Vegetable Crops, UC Davis; L. J. Wyland is Staff Research Associate, Department of Vegetable Crops, UC Davis; J. A. Klein was Postgraduate Researcher, Department of Vegetable Crops, UC Davis. R. F. Smith is Small Farm Advisor, San Benito-Monterey-Santa Cruz counties; and W. E. Chaney and S. T. Koike are Farm Advisors, Monterey-Santa Cruz counties. 